\title{
Apnoea testing to confirm brain death in clinical practice
}

\author{
CA VAN DONSELAAR,* JD MEERWALDT,* J VAN GIJN $\dagger$ \\ From the Departments of Neurology, University Hospital Dijkzigt, ${ }^{*}$ Rotterdam, and University Hospital \\ Utrecht, $\dagger$ Utrecht, The Netherlands
}

SUMMARY In six patients an apnoea test was carried out to confirm brain death according to a protocol recommended in the USA. After ten minutes' apnoea the $\mathrm{pCO}_{2}$ did not reach the target value of $7.98 \mathrm{kPa}(60 \mathrm{~mm} \mathrm{Hg})$ in any of these patients. This was caused by the low initial value and the slow increase of the $\mathrm{pCO}_{2}$. Moreover, we could not confirm the belief that the necessary duration of the apnoea test can be predicted by assuming a rise of the $\mathrm{pCO}_{2}$ of $0.33 \mathrm{kPa}(2.5 \mathrm{~mm} \mathrm{Hg})$ per minute.

The absence of spontaneous breathing is an essential criterion for the diagnosis of brain death. In order to confirm apnoea, the $\mathrm{pCO}_{2}$ level must be high enough to provide supramaximal stimulation of the respiratory centre, as otherwise a posthyperventilation apnoea could be misinterpreted as a permanent apnoea. $^{1}$

Various methods of performing an apnoea test have been recommended. According to the method proposed in the UK, the patient is preoxygenated with $100 \%$ oxygen for 10 minutes. Subsequently, lowering the rate of the ventilator or delivering a mixture of $5 \%$ carbon dioxide and $95 \%$ oxygen for 5 minutes is expected to increase the $\mathrm{pCO}_{2}$ to $5 \cdot 3 \mathrm{kPa}$ $(40 \mathrm{~mm} \mathrm{Hg})$ or higher at the beginning of the apnoea test. Ten minutes of disconnection from the ventilator would then be amply sufficient for the $\mathrm{pCO}_{2}$ to rise above the target value of $6.65 \mathrm{kPa}(50 \mathrm{~mm} \mathrm{Hg}) .{ }^{2}$ During the apnoea test oxygen is administered through an endotracheal tube at a rate of six litres per minute.

In the USA it is recommended to pre-ventilate the patient for 10 minutes, either with a mixture of $5 \%$ carbon dioxide and $95 \%$ oxygen, or with $100 \%$ oxygen. A disconnection of 10 minutes would then

\footnotetext{
Address for reprint requests: Dr CA van Donselaar, Department of Neurology, University Hospital Dijkzigt, 40 Dr. Molewaterplein, 3015 GD Rotterdam, The Netherlands.
}

Received 23 July 1985 and in revised form 20 November 1985. Accepted 23 November 1985 usually be sufficient to reach the required $\mathrm{pCO}_{2}$ level of $7.98 \mathrm{kPa}(60 \mathrm{~mm} \mathrm{Hg})$. Again six litres oxygen per minute are given through an endotracheal tube during the test. ${ }^{3}$

In the present study we tested the method advised in the USA of pre-ventilating the patient for 10 minutes with $100 \%$ oxygen, followed by disconnection from the respirator for at least 10 minutes. In addition, we tested the notion that it is possible to predict the required duration of the apnoea test from the initial $\mathrm{pCO}_{2}$ level by assuming that the $\mathrm{pCO}_{2}$ rises with $0.33 \mathrm{kPa}(2.5 \mathrm{~mm} \mathrm{Hg})$ per minute. ${ }^{4}$

\section{Methods}

The apnoea test was carried out in six patients, five of whom were women: the age was 35 years in one patient and 54-57 in the other five. All patients fulfilled the following criteria:

(1) Structural brain damage was confirmed by CT scanning: subarachnoid haemorrhage in three patients, thrombosis of the superior sagittal sinus in patient no 3, cerebral concussion in patient no 5 , and cerebral haemorrhage in patient no 6.

(2) No evidence of drug intoxication or of metabolic disturbances. The temperatures in all patients ranged from 34.5 to $35.9^{\circ} \mathrm{C}$. All patients were in a well-nourished state. None of the patients was suffering from severe lung disease.

(3) Absence of pupillary responses to light, corneal reflexes, oculocephalic, oculovestibular and coughing reflexes. No motor responses to painful stimuli applied to the face or to the arms.

(4) Isoelectric EEG. 


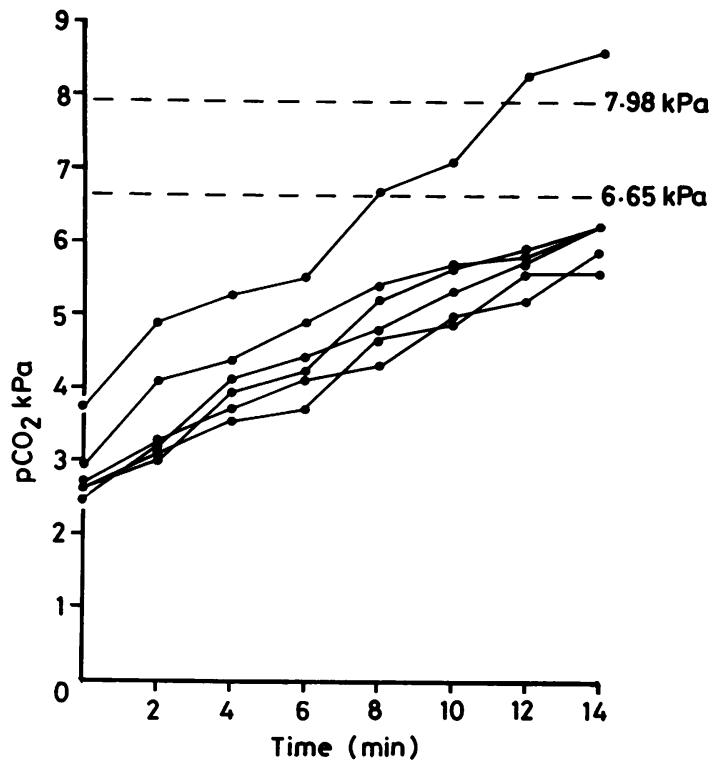

Fig Rise of $\mathrm{pCO}_{2}$ in six presumably brain-dead patients during apnoea. The dotted lines represent the levels of $\mathrm{pCO}_{2}$ that are required for the diagnosis of brain death in the UK (lower line) and the USA (upper line).

All patients were pre-ventilated with $100 \%$ oxygen for 10 minutes, while the rate of the ventilator was not changed. After this period the patient was disconnected for 14 minutes, while six litres of oxygen per minute were administered through an endotracheal tube. Via an arterial line, the blood pressure was continuously measured and blood samples were taken immediately after disconnection and then every two minutes. The samples were kept on ice and blood gas analysis was performed immediately after the test. The values were corrected for the temperature of the patient. Heart rate and respiration curves were visible on a monitor.

\section{Results}

None of the patients started to breathe during the test or made breathing-like movements. There were no disturbances of heart rate or changes in blood pressure.

The oxygenation remained adequate during the test. At the beginning of the test the average $\mathrm{pO}_{2}$ was $52.1 \mathrm{kPa}(392 \mathrm{~mm} \mathrm{Hg})$, the range $37 \cdot 3-60 \cdot 0 \mathrm{kPa}$ $(281-451 \mathrm{~mm} \mathrm{Hg})$. At the end the mean $\mathrm{pO}_{2}$ was $46 \cdot 3$ $\mathrm{kPa}(346 \mathrm{~mm} \mathrm{Hg})$, the range $14 \cdot 8-57 \cdot 2 \mathrm{kPa}(111-430$ $\mathrm{mm} \mathrm{Hg}$ ). The $\mathrm{pH}$ decreased from an average of 7.55 $(7 \cdot 43-7 \cdot 67)$ to $7.29(7 \cdot 16-7 \cdot 38)$, with an average decrease of 0.019 per minute $(0.015-0.021)$.

The figure shows the increase in $\mathrm{pCO}_{2}$ per patient. At the beginning of the test, the $\mathrm{pCO}_{2}$ had a mean value of $2.8 \mathrm{kPa}(21 \mathrm{~mm} \mathrm{Hg})$, and a range of $2.4-3.7$ $\mathrm{kPa}(18-28 \mathrm{~mm} \mathrm{Hg})$. At the end the average $\mathrm{pCO}_{2}$ was $6.45 \mathrm{kPa}(49 \mathrm{~mm} \mathrm{Hg})$, the range $5.6-8.6 \mathrm{kPa}$ $(42-65 \mathrm{~mm} \mathrm{Hg})$. In only one patient the $\mathrm{pCO}_{2}$ exceeded the limit of $6.65 \mathrm{kPa}(50 \mathrm{~mm} \mathrm{Hg})$ after 8 minutes of apnoea, and also the limit of $7.98 \mathrm{kPa}$ $(60 \mathrm{~mm} \mathrm{Hg})$ after 12 minutes of apnoea. The increase over the whole period showed an average of $0.26 \mathrm{kPa}$ or $1.95 \mathrm{~mm} \mathrm{Hg}$ (range $0.21-0.35 \mathrm{kPa}$ or $1.6-2.6 \mathrm{~mm} \mathrm{Hg}$ ) per minute and was not strictly linear. Over the first 4 minutes the increase was on average $0.34 \mathrm{kPa}$ or $2.6 \mathrm{~mm} \mathrm{Hg}$ (range $0.23-0.48 \mathrm{kPa}$ or $1.7-3.6 \mathrm{~mm} \mathrm{Hg}$ ) per minute and over the following 10 minutes $0.23 \mathrm{kPa}$ or $1.7 \mathrm{~mm} \mathrm{Hg}$ (range $0.13-0.33$ $\mathrm{kPa}$ or $1.4-2.5 \mathrm{~mm} \mathrm{Hg}$ ) per minute (Student's $t$ test for paired samples $p<0.03$ ). The table shows the values of the $\mathrm{pCO}_{2}$ for each patient. The increase in $\mathrm{pCO}_{2}$ over the last 10 minutes of the test was extrapolated in order to estimate how long the test should have lasted to reach a $\mathrm{pCO}_{2}$ value of $6.65 \mathrm{kPa}(50$ $\mathrm{mm} \mathrm{Hg})$ or $7.98 \mathrm{kPa}(60 \mathrm{~mm} \mathrm{Hg})$. The mean and range of these intervals were 16 minutes (8-19) and 22 minutes (12-26), respectively. Finally we calculated the predicted $\mathrm{pCO}_{2}$ value after 14 minutes' apnoea assuming an increase of $0.33 \mathrm{kPa}(2.5 \mathrm{~mm} \mathrm{Hg})$ per minute. ${ }^{4}$ According to this method an apnoea test of 14 minutes should in all patients have been sufficient to have the $\mathrm{pCO}_{2}$ rise above $6.65 \mathrm{kPa}(50 \mathrm{~mm} \mathrm{Hg})$, but in fact this occurred only in one patient (no 3).

Table Apnoea test in 6 presumably brain-dead patients

\begin{tabular}{|c|c|c|c|c|c|c|c|c|}
\hline \multirow[t]{2}{*}{ Patient no } & \multicolumn{3}{|c|}{$p \mathrm{CO}_{2}$ in $\mathrm{kPa}$} & \multicolumn{2}{|c|}{ Rise of $\mathrm{pCO}_{2}$ in $\mathrm{kPa} / \mathrm{min}$} & \multicolumn{2}{|c|}{$\begin{array}{l}\text { Estimated time in minutes for } \\
\text { the } \mathrm{pCO}_{2} \text { to reach }\end{array}$} & \multirow[t]{2}{*}{$\begin{array}{l}\text { Expected pCO } \mathrm{CO}_{2} \text { after } 14 \mathrm{~min} \\
\text { of apnoea } \text { in }_{\mathrm{kPa}}\end{array}$} \\
\hline & 0 & 10 & 14 min. apnoea & $0-14 \min$ & $4-14 \min$ & $6.65 \mathrm{kPa}$ & $7.98 \mathrm{kPa}$ & \\
\hline $\begin{array}{l}1 \\
2 \\
3 \\
4 \\
5 \\
6\end{array}$ & $\begin{array}{l}2.4 \\
2.9 \\
3.7 \\
2.7 \\
2.6 \\
2.6\end{array}$ & $\begin{array}{l}5 \cdot 3 \\
5 \cdot 7 \\
7 \cdot 1 \\
5 \cdot 0 \\
5 \cdot 7 \\
4 \cdot 9\end{array}$ & $\begin{array}{l}6 \cdot 2 \\
6.2 \\
8.6 \\
5.9 \\
6.2 \\
5 \cdot 6\end{array}$ & $\begin{array}{l}0.27 \\
0.24 \\
0.35 \\
0.23 \\
0.26 \\
0.21\end{array}$ & $\begin{array}{l}0.21 \\
0.18 \\
0.33 \\
0.22 \\
0.23 \\
0.21\end{array}$ & $\begin{array}{r}17 \\
17 \\
8 \\
18 \\
16 \\
19\end{array}$ & $\begin{array}{l}23 \\
24 \\
12 \\
24 \\
22 \\
26\end{array}$ & $\begin{array}{l}7 \cdot 0 \\
7 \cdot 5 \\
8 \cdot 3 \\
7 \cdot 3 \\
7 \cdot 2 \\
7 \cdot 2\end{array}$ \\
\hline
\end{tabular}

$\mathrm{pCO}_{2}$ values at the beginning and after 10 and 14 minutes. The times necessary to reach a pCO ${ }_{2}$ of $6.65 \mathrm{kPa}(50 \mathrm{~mm} \mathrm{Hg})$ and $7.98 \mathrm{kPa}$ $(60 \mathrm{~mm} \mathrm{Hg})$ were extrapolated from the rise from 4 to 14 minutes. In the last column, the expected pCO ${ }_{2}$ after 14 minutes' apnoea is calculated
following the method of Ropper. ${ }^{4}$ 


\section{Discussion}

Our results show that 10 minutes of apnoea in six presumably brain-dead patients, preceded by ventilation with $100 \%$ oxygen for 10 minutes and accompanied by administration of six litres of oxygen per minute through an endotracheal catheter did not cause hypoxia $(95 \%$ confidence limits for all cases $54-100 \%$ ), but failed to result in $\mathrm{pCO}_{2}$ levels required for maximal stimulation of the respiratory centre. In five out of six patients the rise was insufficient to reach even the lowest of the two official limits $(95 \%$ confidence limits 36-100\%). This can be explained partly by the low $\mathrm{pCO}_{2}$ levels at the onset of apnoea in our patients and partly by the slow increase of the $\mathrm{pCO}_{2}$, at an average of $0.26 \mathrm{kPa}(1.95 \mathrm{~mm} \mathrm{Hg})$ per minute.

In previous studies on brain-dead patients the initial $\mathrm{pCO}_{2}$ values were higher (mean $4.4 \mathrm{kPa}$ $(33 \mathrm{~mm} \mathrm{Hg}){ }^{5} \quad 4.5 \mathrm{kPa}(34 \mathrm{~mm} \mathrm{Hg}){ }^{6} \quad 3.3 \mathrm{kPa}$ $(25 \mathrm{~mm} \mathrm{Hg})^{78}$ and $\left.5.2 \mathrm{kPa}(39 \mathrm{~mm} \mathrm{Hg})^{9}\right)$, and the increase of the $\mathrm{pCO}_{2}$ per minute was greater (mean $0.43 \mathrm{kPa}(3.2 \mathrm{~mm} \mathrm{Hg})$ per minute in a 10 minute apnoea test in seven patients, ${ }^{5} 0.32 \mathrm{kPa}(2.4 \mathrm{~mm} \mathrm{Hg})$ per minute in 14 patients in an apnoea test of 20 minutes, ${ }^{6} 0.34 \mathrm{kPa}(2.58 \mathrm{~mm} \mathrm{Hg})$ per minute after an unknown period in 36 patients, ${ }^{4} 0.34 \mathrm{kPa}(2.6$ $\mathrm{mm} \mathrm{Hg}$ ) per minute in a 14 minute apnoea test in 12 patients ${ }^{8}$ and $0.53 \mathrm{kPa}(4 \mathrm{~mm} \mathrm{Hg})$ per minute in a 5 minute apnoea test in 10 brain-dead children ${ }^{9}$ ). The duration of the apnoea test is important because we found that the increase is not linear. It is possible that the rise in $\mathrm{pCO}_{2}$ is related to the initial $\mathrm{pCO}_{2}$, but we could not confirm this hypothesis from our own observations, because the initial values were within a small range.
Instead of preoxygenation only, the method of subsequently preventilating the patient with a mixture of $5 \%$ carbon dioxide and $95 \%$ oxygen or of lowering the rate of the ventilator may be better suited to reach the desired level of $\mathrm{pCO}_{2}$ after 10 minutes of apnoea. Until such a method has been rigorously tested, blood gas determinations are necessary both at the start and at the end of the apnoea test.

We thank Mrs J Doornbosch-Konijn for secretarial help.

\section{References}

${ }^{1}$ Plum F, Brown HW, Snoep E. Neurologic significance of posthyperventilation apnea. JAMA 1962;181:1050-5.

${ }^{2}$ Pallis C. ABC of brainstem death. London $\mathrm{Br} \mathrm{Med} J$, Tavistock, 1983.

${ }^{3}$ Special communication. Guidelines for the determination of death. JAMA 1981;246:2184-6.

${ }^{4}$ Ropper AH, Kennedy SK, Russell L. Apnea testing in the diagnosis of brain death. $J$ Neurosurg 1981;55:942-6.

${ }^{5}$ Schafer JA, Caronna JJ. Duration of apnea needed to confirm brain death. Neurology (Minneap) 1978;28: 661-6.

${ }^{6}$ Pitts LH, Kaktis J, Caronna J, Jennet S, Hoff JT. Brain death, apneic diffusion oxygenation, and organ transplantation. J Trauma 1978;18:180-3.

${ }^{7}$ Moeschler O, Tribolet $\mathbf{N}$ de. Définition de l'apnée dans le diagnostic de mort cérébrale. Schweiz Med Wschr 1982;112:443-8.

${ }^{8}$ Milhaud A, Riboulot M, Gayet H. Disconnecting tests and oxygen uptake in the diagnosis of total brain death. Ann NY Acad Med 1978;315:241-51.

${ }^{9}$ Outwater KM, Rockoff MA. Apnea testing to confirm brain death in children. Crit Care Med 1984;12:357-8. 